\title{
Gauging Food Allergy Knowledge among Hospitality Students
}

\author{
Norrina Bt Din (Corresponding author) \\ Faculty of Hotel and Tourism Management, University Teknologi MARA, Penang \\ 13700 Permatang Pauh, Penang, Malaysia \\ Tel: 60-4-328-3677 E-mail: norrina7@gmail.com
}

Basri Rashid

School of Tourism, Hospitality and Environmental Management

UUM College of Law, Government and International Studies

Universiti Utara Malaysia, 06010 UUM Sintok

Kedah Darul Aman, Malaysia

Tel 60-4 928-8150/8191_E-mail: basri@uum.edu.my

Kamal Izzuwan Ramli

School of Tourism, Hospitality and Environmental Management

UUM College of Law, Government and International Studies

Universiti Utara Malaysia, 06010 UUM Sintok

Kedah Darul Aman, Malaysia

Tel: 60-4-928-8194Ｅ-mail: izzuwan@uum.edu.my

Received: August 13, 2014 Accepted: November 3, 2014 Published: February 1, 2015

doi:10.5296/jmr.v7i2.6947ＵRL: http://dx.doi.org/10.5296/jmr.v7i2.6947

\begin{abstract}
Cases involving food allergy and their effects seem to be growing all around the world. The effects of food allergy can range from mild to severe and even lead to death. It is also noted that students are among the frequent victims of food allergy. The cure for food allergy is
\end{abstract}


unknown. Thus, a form of intervention is needed to prevent food allergy from occurring. In order to do so, an adequate level of knowledge concerning food allergy is crucial. This study, therefore, explores the level of awareness and knowledge on food allergy among hospitality students in Malaysia. Survey method was utilized in this study and questionnaires were distributed to 150 students specifically who are studying hospitality program at two universities in the Northern region of Malaysia. Results revealed that majority of the respondent have an average knowledge pertaining to food allergy issue. This paper revealed the general knowledge, awareness and perceptions of hospitality students pertaining to food allergy. The implication of the study would benefit the public. Proper development of food allergy syllabus will enhance student knowledge and perhaps will help them to prepare and serve wholesome food to the customers.

Keywords: Allergy awareness, knowledge, hospitality student, food allergy, food allergy sufferers 


\section{Introduction}

The term of food allergy is referred to the body's abnormal responses to harmless foods, and this caused when a person eats something that the immune system incorrectly identifies as harmful. There are more than 170 foods that identified to stimulate food allergic reactions (Boye, 2012). The food protein in food such as eggs, milk, tree nut, shellfish, soy, peanut and wheat may result to a broad range of symptoms that affected food allergy sufferers. These foods classified as big eight food allergens (Payne, 2011). The reactions attacked the skin, respiratory system and gastrointestinal system. To be specific, the skin will become itchy and redness. The respiratory system affected such as short breath; the heartbeat become slower or faster, wheezing, swelling lips and tongue. Whereas for the gastrointestinal system, the reactions are bloating, nausea, vomit, diarrhea and abdominal pain (Pietzak, 2012). More severe individual with food allergy may experience anaphylaxis reaction that may drop the blood pressure, loss of consciousness, blur visions and the worst is death (Gaspar-Marques et al., 2014). Food that healthy people, usually, consumed become dangerous to the food allergy sufferers (Stjerna, Vetander, Wickman, \& Olin Lauritzen, 2014). Food that suggested by Malaysian Dietary Guidelines for Children and Adolescent ( $\mathrm{MOH}, 2013)$ such as milk, soy (soy sauce and tempe, bean curd), banana, fish, oyster, squid, noodle, bread, tuna and sardine also can triggered food allergic (Boye, 2012).

In addition, having known about food that can trigger food allergic reaction therefore it is crucial to disclose the issues arise regarding the incident of food allergy. The parents with food allergy sufferers and food allergy sufferers are facing immense challenges. The parents and food allergy sufferer are demanding to have a safe school and foodservice establishment for their children. Once the food allergic reaction triggered, it is involved not only medical costs but also need diet restriction and meticulous care. The reactions proved to increased anxiety, demoralize, limited socialization and quality of life is decreased (Gaspar-Marques et al., 2014). Up to date, there is no cure for food allergy and the only way to prevent the reaction is to avoid expose and consumed food allergen (Stjerna et al., 2014 \& Burks et al., 2012). Western and European countries already implement allergen free school and environment for this susceptible populations (Muraro et al., 2010, Wahl, Stephens, Ruffo, \& Jones, 2014, Sicherer \& Sampson, 2013). Whereas, food allergy studies have been done in Asia as well (Shek \& Lee, 2006). In addition, another research was discovered about managing food in specifically in Korean school (Kim, Yoon, Kwon, Kim, \& Han, 2012), Japan (Imamura, Kanagawa, \& Ebisawa, 2008) and Singapore (Lee et al., 2010). Furthermore, Redhwan, Low, Mustafa, Robert and Ali, (2011) assessed the perception among medical student (Redhwan, Low, Mustafa, Robert, and Ali, 2011), however, gauging food allergy knowledge among hospitality student have not yet discover.

With the gap, currently in Malaysia, there is only food safety training regarding hygiene and sanitation available but for food allergy training remain unknown. Therefore, this study attempts to investigate the level of knowledge pertaining to food allergy among hospitality student. The reason behind it is due to the universities keep on producing a huge amount of graduates in hospitality and predicted that they will enter into the hospitality industry. For that reason, assessing their knowledge is crucial in order to determine the level of food 
allergy knowledge among them. Knowledge regarding food allergy should not be ignored since this population is growing, and their life depends on the food that they consumed. Wrong ingest food, will cause life threatening to them. The hospitality student not only must equip themselves with delivering better service, but they also required giving satisfaction to the customer by meeting the need and requirement of this susceptible population. Therefore, this study intends to investigate the level of food allergy knowledge among the hospitality student in northern region universities.

\section{Literature Review}

\subsection{Food allergy population}

The estimation for world population about 220-250 million people who have suffered from the allergic diseases (Pawankar, Canonica, Holgate \& Lockey, 2011). According to Sicherer \& Sampson, (2011) the prevalence of food allergy also increased in the United States. Many researchers are trying to solve the problem and till now they keep on trying to settle this problem (Herman \& Burks, 2011). The researchers further added food avoidance is the primary action in order to prevent food allergy reactions. Thus, the food allergy sufferers need to take extra precaution about food selections and food service establishment. Whereas in Europe, the researchers identified the most population affected with food allergy is children aged from 5 to 14 years (Caffarelli et al., 2011).

In Asia namely Taiwan, the food allergy sufferers not only experience the food allergies reaction but, however, they are re-experienced it due to the exposure and wrongly consumed food allergen. Approximately $77 \%$ out from the 30018 food allergy sufferers surveyed by the researchers re-experienced the occurrence of food allergy incident (Wu et al., 2012). Furthermore, as estimated by Pawankar et, al (2011) for about 10-15\% children in Malaysia having food allergies. The increasing of this susceptible population should carefully pay attention by the public. The life will be jeopardized by the lack of public awareness pertaining food allergy.

\subsubsection{Definition of Knowledge}

The definitions of knowledge are belief, understanding, familiarity and awareness towards information, facts and skill. Knowledge obtained from education by observing, learning and perceive and interpretation. It is also gain through experience. Thus knowledge as defined by Hunt (2003 p. 101) “An individual's behavior and performance depend both on the knowledge that has been acquired through learning, practice and experience as well as the sensory receptors and the system of muscles, organs, etc". For instance in this case, knowledge pertaining to food allergy is a concept on how different perceived applicable to food allergy. It includes the issue such as the definition of food allergy, the food allergen; provide allergen-free food, the symptoms and reaction of it. Therefore as described by Serradell-Lopez, Lara, Castillo, \& González, (2010), knowledge is someone perceived as belief. In spite of only focuses on knowledge, hospitality student are future leader and future worker in the industry therefore the first concept discussed by Drucker (1992) said that, the 
greatest asset in an organization is knowledge worker. According to Serradell-Lopez et al., (2009) the knowledge gained not only for memorizing and learning instead it is useful when the knowledge is implement and carve up for the benefits of all. As a consequence, the food allergy sufferer must also to convey the information food that they must avoid to the food handler. At the same time if the food handler has some basic knowledge regarding food allergy, hence, the incident of food allergy will likely reduce (Behrmann, 2010). Another important finding was definition knowledge from Japanese perspective other than Western point of view, Nonaka \& Takeuchi (1995) stated knowledge is recognized by formal education that is explicit knowledge and also through on the job training or hands on that is classified as tacit knowledge. Finally, knowledge management can absorb knowledge from outside and inside of an organization with proper implementation process. Thus, will helps to meet the customer demand (Ouintas et al. 1997).

Many researchers embark on the knowledge and behaviour studies. For instance, the previous study was conducted by Sharma and Romas (2008) discovered that knowledge towards particular situation or phenomenon can lead to behavior change. In addition, with sufficient awareness and knowledge is crucial for altering behavior. However, based on the related study on knowledge, it is not confirmed that, only knowledge will lead to behavior change. Furthermore, behavior will change due other variables too such as value, beliefs and attitudes found as affected factor for behavior modifications as well (Sharma and Romas, 2008). From a psychological perspective, the existence theories and model help other researchers to uncover about behavior modifications. For instance the Theory of Planned Behavior (Ajzen, 2005) and Health Belief Model (Rosenstock, Strecher \& Beckers, 1988). According to Rimal (2000), sufficient knowledge is crucial in order to modify behavior towards a certain situation. For instance, for most health behavior knowledge is link with the self-efficacy. Previous study shown strong evident on less knowledge among chefs towards coeliac diseases will result in high risk when the sufferers are eating outside from away from home (Karajeh, Hurlstone, Patel, \& Sanders, 2005). Having known about the knowledge, consequently, it is essential to uncover the knowledge pertaining to food allergy in the hospitality industry.

\subsubsection{Knowledge of food allergy and foodservice industry}

Due to hectic and busiest lifestyle, dining out become alternatives for the community. Dining out for most individual with food allergy is a risk. Since most of the foodservice establishment did not show detail ingredients lists in the menu card, therefore, the food handlers or chef are hardly to reveal the ingredients that used in preparation and cooking. Thus, the food allergy sufferer having difficulties for choosing a place to dine in. The food allergy sufferer would face the food allergic reaction if they consumed or exposed to the food allergen. The reason is the reaction of food allergy reactions resulted from mild to severe or lead to death (Sicherer, 2011).

Restaurant workers felt that the customer have to be responsible for making known to them about the allergies at the time the food ordered (Abbot, Byrd-Bredbenner and Grasso, 2007). However, as allergens were not listed on the menu, the customer jump into conclusion that 
the food served was safe (Abbot et.al, 2007). Therefore, there is a false impression about expectations between food allergy sufferer and foodservice workers. Foodservice worker relies on the food allergy sufferer to make inform about food that they are allergic to when place an order. Whereas, the food allergy sufferers are depending on the foodservice worker to inform them about the food allergen contain in the dishes. Thus, it may increase the incident of food allergy reaction among customer while dinning in the restaurant (Ajala et al., 2010). Moreover, factors of lack awareness and knowledge among restaurant manager on food allergy customers were found to be a major challenge in providing allergen-free food while dining out (Abott et.al, 2007). Lack of formal training towards food allergen program is another factor that contributed to the failure in managing the allergies cases from happening in the restaurant (Worm et al., 2010). In particular, there is a study was conducted by telephone survey among owner, managers, waiter and chefs in different types of restaurants such as African, American, Asian, English, European and Italian in Brighton, United Kingdom (Bailey, Albardiaz, Frew, \& Smith, 2011). The authors discovered that, there is a lack of awareness and knowledge about food allergy. In addition, the restaurants staff should prepare foods that are wholesome and safely consumed by customers. Finally, it is relevant in protecting food allergy customer by integrated food safety training and food allergy information such as on how to prepare food safely to this allergic customer. Negligence of it may cause fatal to the sufferer. Hence, the restaurant staff should have the responsibility to protect this susceptible population.

On the other hand, in United States of America, the Cornell University researchers have conducted research and developed a food allergy fact sheet in order to protect this population. The information gathered from twenty experts in food allergy such as an allergist, dietitian, pediatrics, health specialist, foodservice experts including restaurateurs, allergy education experts and food policy experts to gather relevant information. The most striking result to emerge from the study was the development of food allergy fact sheet in New Jersey. The fact sheet included the information required to prepare allergen-free food. In addition, it also incorporated on how to avoid cross-contamination during food preparation together with photo and step by step (Abbot et.al, 2007). Furthermore, the food allergy fact sheet was tested to twenty eights participants including restaurants owner, foodservice operations manager and chef. Overall response was very positive; most of them pointed out, poster is preferable made by durable materials and written in English and Spanish for better purposes. Moreover, instead of asking foodservice employees to declare food allergen, the foodservice personnel also required the food allergy customer to declare and inform them about the food allergen. Thus, both parties should work together rather than blaming each other if the incidents keep on occurring.

Recently, most food service workers reported having limited awareness and knowledge towards a life-threaten food allergy (Choi \& Rajagopal, 2013a). In addition, lack of awareness on understanding the needs of food allergic among public also proved to have an adverse impact towards the food allergy population (Peniamina, Bremer, Conner, \& Mirosa, 2014). Even though the study pertaining to food allergy knowledge is still carried out all over world, however, the results of the study majority of the results demonstrated that there is a 
lack of food allergy knowledge among the food handler. In Malaysia, the perception of food allergy knowledge was assessed among forty medicals student. Majority of the participant can recognize and diagnosed the food allergy symptoms however there is a misapprehension that food allergy can be cured. The fact that, food allergy cannot be cured, and researchers all over the world keep on trying to solve this problem (Russell \& Huber, 2013). Additionally, food allergy knowledge among the medical student should improve in order to protect public from the food allergy incidents. Thus, improve knowledge among medical student, and hospitality student are crucial to protecting this susceptible population. The reason is due most of the food handlers have educational background on food preparation. Some of them are graduated and will be graduated from diploma and bachelor degree and going to work in fast food outlet, hotels and other foodservice outlets including transportation such as cruise and airlines. Perhaps, the outcome of this will assist in the setup the need to for developing better curricular and at the same time create the awareness on how to prepare safe food to the customer with food allergy.

\section{Methodology}

In obtaining the information, a questionnaire was gain after extensive review of the literature related to the topic. The questions were adapted and adopted from the previous study by Choi and Rajagopal (2013). Only a minor amendment was done to suit with the local respondents. The samples of the population were among hospitality students in two universities in the Northern region namely Universiti Teknologi MARA and Universiti Utara Malaysia. The hospitality student was chosen because they will be working in the hospitality industry. Some of them already have experienced working in this industry. After set the appointments with the agreed date and time, the questionnaire was successfully undertaken, and researcher was entirely satisfied with the answers provided and grateful with commitment and the cooperation given by all of them. Nevertheless, out of 200 questionnaire were distributed, therefore only 150 usable questionnaire returns. Data was analyzed by using SPSS (Statistical Package for Social Science) version 22.

\section{Result}

\subsection{Respondents Profile}

In obtaining the information, a questionnaire was gain after extensive review of the literature related to the topic. The questions were adapted and adopted from the previous study by Choi and Rajagopal (2013). Only a minor amendment was done to suit with the local respondents. The samples of the population were among hospitality students in two universities in the Northern region namely Universiti Teknologi MARA and Universiti Utara Malaysia. The hospitality student was chosen because they will be working in the hospitality industry. Some of them already have experienced working in this industry. After set the appointments with the agreed date and time, the questionnaire was successfully undertaken, and researcher was entirely satisfied with the answers provided and grateful with commitment and the cooperation given by all of them. Nevertheless, out of 200 questionnaire were distributed, 


\section{Macrothink}

Journal of Management Research

ISSN 1941-899X 2015, Vol. 7, No. 2

therefore only 150 usable questionnaire returns. Data was analyzed by using SPSS (Statistical Package for Social Science) version 22.

Table 1. Knowledge on food allergy

Questions on food allergy knowledge
1. How soon does a food allergy reaction occur after the food is
consumed
a) Immediately or within a few hours after the food is consumed.
111
74.0 ${ }^{\mathrm{b}}$
b) Twenty-four hours after the food is consumed.
c) Thirty-six hours after the food is consumed.
d) Forty-eight hours after the food is consumed.
4

2. Which body system can be affected by a food allergy reaction?
a) Gastrointestinal tract
$11 \quad 7.3$
b) Respiratory system
$7 \quad 4.7$
c) Skin
40
d) All the above
92
$61.3^{\mathrm{b}}$

3. Food allergies are caused by the body's negative reaction to which of the following?
a) fat
17
b) Proteins
c) Carbohydrates
d) Trans-fatty acids

4. Which of the following does not belong in the top eight food allergens?
a) Potato
42
28.0 ${ }^{\text {b }}$
b) Wheat
52
34.7
c) Shrimp
24
16.0
d) Tofu

5. Which of the following items are risky for guests who have food allergies?
a) Fried foods
b) Desserts
c) Complex dishes with many ingredients
d) All of the above

6. Which of the following should service staff do in order to prevent an allergic reaction? 
a) Cook food to the right internal temperature

b) Be able to identify ingredients in the menu items upon customer's request, and determine if it contains any commonly known allergens

c) Use dishwasher for washing dishes

d) Keep foods safe from microbial growth

7. Which of the following is the best treatment for controlling a severe food allergic reaction?
a) Benadryl
b) Pseudoephedrine
96.0
c) Sudafed

32.0
d) Epinephrine

$8 \quad 5.3^{\mathrm{b}}$
e) I do not know

8. Which of the following practices could cause cross contact?

a) Using the same utensils for preparing allergen-containing foods, 43 as well as allergen-free foods.

b) Preparing allergen-free food on a countertop that has not been thorough cleaned and sanitized.

c) Not washing your hands but using a fresh pair gloves before handling the allergen-free food.

9. If guest is experiencing an allergic reaction, what is the first thing you should do?
a) determine which food the patron is allergic to
b) Investigate how the food allergic reaction could have happened
c) Defend the food allergy policies of your establishment
d) Get medical help immediately

10. Why can fried foods be dangerous for individuals with food allergies?

a) The high-fat content in fried food makes allergic reactions worse.

b) Frying changes the chemical structure of foods.

c) Cross contact with another food protein could occur if the oil were 
used to cook other foods.

d) The high starch content makes allergic reactions worse.

12

8.0

11. Which of the following is the definition of allergen cross-contact?

a) Contact between raw and cooked foods. $\quad 39 \quad 26.0$

b) Contact between allergen-containing foods and non-allergen $\quad \mathbf{7 0} \quad \mathbf{4 6 . 7}^{\mathrm{b}}$ containing foods.

c) Contact between allergen-containing food and raw meat

d) Contact between allergen-containing foods and dairy products.

\subsubsection{Discussion}

The outcome from this study provided insight into food allergy knowledge among hospitality student from two universities in the Northern region. In general, the respondents were knowledgeable in food allergy and had basic knowledge pertaining to food allergy reactions. In addition, they also manage to identify body part that can be affected by food allergy reactions. However, most of the respondents identified wrongly for the big eight allergen. Lack of knowledge to identify the big eight allergen will likely to risk the food allergy sufferer (Bailey et al., 2011). This is due to, the food allergy sufferer relies on the food handlers to provide them safe food and wholesome. Thus, this result strongly supported that the food handler plays an important roles in providing safe food to the food allergy sufferers.

Furthermore, this result also established that improve education and training to the respondents are crucial to give better food allergy information. Protecting food allergy sufferer does not only depend on the food handler alone, but public must aware with the need and requirement for this susceptible population (Choi \& Rajagopal, 2013a). For instance, most of the hospitality industries provide special facilities for the disabled people with wheel chair such as provides toilet and path to them, but, unfortunately, the food allergy sufferer is neglected by public. This susceptible population is physically looking no different with the normal person but the food that we consumed will actually harmful to them. The number of food allergy victims leads to death is keeping on increasing due to negligence (Bock, Munoz-Furlong \& Sampson, 2001). The food allergy sufferer and their parents are struggling to survive but if the public just ignored it, the incidents of food allergy will occur. The food allergy sufferer will re -experienced the food allergy reactions as reported by $\mathrm{Wu}$ et al., ( 2012) if the public just ignored about the food allergy issue. As a result, the food allergy sufferer and parents will face tremendous challenges and they also have to bare the medical cost, trauma, demoralized and the quality of life is dwindle (Gaspar-Marques et al., 2014).

Several methods can be used to improve knowledge and awareness by doing public campaign and awareness. Additionally, the lecturers can use classroom training and emphasize more on food allergy topic, including videos, food allergy talk that is sharing the experience, for instance, may be the theirs friend is one the food allergy sufferer. He or she can share the experience and what are the expectation towards providing better service and allergen free food in the hospitality industry. Moreover, an additional certificate will be provided for the 
hospitality student if they completed the module. That is considered as value added to the hospitality student when they are working. Taken together, rather than pointing each other and finding faults thus, the customer and the stakeholders need to cooperate to protect this susceptible population and provide them safe food and better service. In consequence, as mentioned previously, knowledge, awareness and understanding of food allergy is crucial.

\section{Conclusion}

This study was found that, hospitality student have some basic knowledge pertaining to food allergy. However, the knowledge still can be improved if the universities can educate them more and provide more information on safe handling food for the susceptible population. Thus, this study will serve as a base for future studies in a related field. This finding also can provide insight for future research such as which part of food allergy knowledge should focus into, in order to improve knowledge or to make any intervention pertaining to food allergy issues. The development of syllabus and module pertaining to food allergy will helps the hospitality student to improve knowledge.

\section{Acknowledgement}

Thanks for my supervisors Dr Basri and Dr. Kamal for their guidance.

\section{References}

Abbot, J. M., Byrd-Bredbenner, C., \& Grasso, D. (2007). "Know before You Serve": Developing a Food-Allergy Fact Sheet. Cornell Hotel and Restaurant Administration Quarterly, 48(3), 274-283. http://dx.doi.org/10.1177/0010880407302779

Ajala, A. R., Cruz, A. G., Faria, J. A. F., Walter, E. H. M., Granato, D., \& Sant, A. S. (2010). Food allergens: Knowledge and practices of food handlers in restaurants. Food Control, 21(10), 1318-1321. http://dx.doi.org/10.1016/j.foodcont.2010.04.002

Ajzen, I. (2005). Attitudes, personality, and behavior. McGraw-Hill International.

Bailey, S., Albardiaz, R., Frew, a J., \& Smith, H. (2011). Restaurant staff's knowledge of anaphylaxis and dietary care of people with allergies. Clinical and Experimental Allergy. Journal of the British Society for Allergy and Clinical Immunology, 41(5), 713-7. http://dx.doi.org/10.1111/j.1365-2222.2011.03748.x

Behrmann, J. (2010). Ethical principles as a guide in implementing policies for the management of food allergies in schools. The Journal of School Nursing. The Official Publication of the National Association of School Nurses, 26(3), 183-93. http://dx.doi.org/10.1177/1059840510364844

Bock, S. A., Mu-oz-Furlong, A., \& Sampson, H. A. (2001). Fatalities due to anaphylactic reactions to foods. Journal of Allergy and Clinical Immunology,107(1), 191-193. http://dx.doi.org/10.1067/mai.2001.112031

Boye, J. I. (2012). Food allergies in developing and emerging economies: need for comprehensive data on prevalence rates. Clinical and Translational Allergy, 2(1), 25. 
http://dx.doi.org/10.1186/2045-7022-2-25

Burks, W.s, Tang, M., Sicherer, S, Muraro, A., Eigenmann, P.A., Ebisawa, M., Fiocchi, A., Chiang, W., Chiang, W., Beyer, K., Wood, R., Hourihena, J., Jones, S.M., Lack, G., Sampson, H. A. (2012). ICON: food allergy. The Journal of Allergy and Clinical Immunology, 129(4), 906-920. http://dx.doi.org/10.1016/j.jaci.2012.02.001

Caffarelli, C., Coscia, A., Ridolo, E., Povesi Dascola, C., Gelmett, C., Raggi, V., ... Dall'Aglio, P. P. (2011). Parents' estimate of food allergy prevalence and management in Italian school-aged children. Pediatrics International. Official Journal of the Japan Pediatric Society, 53(4), 505-10. http://dx.doi.org/10.1111/j.1442-200X.2010.03294.x

Choi, J. H., \& Rajagopal, L. (2013a). Food allergy knowledge, attitudes, practices, and training of foodservice workers at a university foodservice operation in the Midwestern $\begin{array}{lllll}\text { United States. } & \text { Food } & \text { 474-481. }\end{array}$ http://dx.doi.org/10.1016/j.foodcont.2012.10.023

Choi, J. H., \& Rajagopal, L. (2013b). Food allergy knowledge, attitudes, practices, and training of foodservice workers at a university foodservice operation in the Midwestern United States. Food Control, $31(2), \quad$ 474-481. http://dx.doi.org/10.1016/j.foodcont.2012.10.023

Drucker, P. (1992). Managing for the future, Truman Talley/ E.P. Dutton, New York, NY

Gaspar-Marques, J., Carreiro-Martins, P., Papoila, A. L., Caires, I., Pedro, C., Araújo-Martins, J., ...\& Neuparth, N. (2014). Food Allergy and Anaphylaxis in Infants and Preschool-Age Children. Clinical Pediatrics. http://dx.doi.org/10.1177/0009922814527502

Herman, E. M., \& Burks, a W. (2011). The impact of plant biotechnology on food allergy. $\begin{array}{llll}\text { Current } \quad \text { Opinion 224-30. } & \text { 22(2), Biotechnology, }\end{array}$ http://dx.doi.org/10.1016/j.copbio.2010.11.003

Hunt, D. P. (2003). The concept of knowledge and how to measure it. Journal of Intellectual Capital, 4(1), 100-113. http://dx.doi.org/10.1108/14691930310455414

Imamura, T., Kanagawa, Y., \& Ebisawa, M. (2008). A survey of patients with self-reported severe food allergies in Japan. Pediatric Allergy and Immunology. Official Publication of the European Society of Pediatric Allergy and Immunology, 19(3), 270-4. http://dx.doi.org/10.1111/j.1399-3038.2007.00621.x

Karajeh, M. a, Hurlstone, D. P., Patel, T. M., \& Sanders, D. S. (2005). Chefs' knowledge of coeliac disease (compared to the public): a questionnaire survey from the United Kingdom. Clinical Nutrition (Edinburgh, Scotland), 24(2), 206-10. http://dx.doi.org/10.1016/j.clnu.2004.08.006

Kim, S., Yoon, J., Kwon, S., Kim, J., \& Han, Y. (2012). Current status of managing food allergies in schools in Seoul, Korea. Journal of Child Health Care: For Professionals Working with Children in the Hospital and Community, 16(4), 406-16. http://dx.doi.org/10.1177/1367493512448128 
Lee, B. W., Aw, M., Chiang, W. C., Daniel, M., George, G. M., Goh, E. N., ... Van \& Bever, H. (2010). Academy of medicine, Singapore-Ministry of Health clinical practice guidelines: management of food allergy. Singapore Medical Journal, 51(7), 599-607.

Malaysia Ministry of Health (MOH). (2013). Malaysian Dietary Guidelines for Children and Adolescents (pp. 1-74). Kuala Lumpur. Retrieved from http://www.moh.gov.my/images/gallery/Garispanduan/MDGChildrenandAdolescentsSummar y.pdf

Muraro, a, Clark, a, Beyer, K., Borrego, L. M., Borres, M., Lødrup Carlsen, K. C., ... \& Zanchetti, M. (2010). The management of the allergic child at school: EAACI/GA2LEN Task Force on the allergic child at school. Allergy, 65(6), 681-9. http://dx.doi.org/10.1111/j.1398-9995.2010.02343.x

Nonaka, I., \& Takeuchi, H. (1995). The knowledge-creating company: How Japanese companies create the dynamics of innovation. Oxford university press.

Ouintas, P., Lefrere, P., \& Jones, G. (1997). Knowledge management: a strategic agenda. Long Range Planning, 30(3), 385-91. http://dx.doi.org/10.1016/S0024-6301(97)90252-1

Pawankar, R., Canonica, W, G., Holgate, S, T., Lockey, R, F. (2011). WAO White Book on Allergy 2011-2012: Executive Summary (p. 36).

Payne, D. (2011). The Association among Food Allergy History, Food Indeuced Anaphylactic Shock and Health Outcome.

Peniamina, R. L., Bremer, P., Conner, T. S., \& Mirosa, M. (2014). Understanding the needs of food-allergic adults. Qualitative health research. http://dx.doi.org/10.1177/1049732314539733

Pietzak, M. (2012). Celiac disease, wheat allergy, and gluten sensitivity: when gluten free is not a fad. JPEN. Journal of Parenteral and Enteral Nutrition, 36(1 Suppl), 68S-75S. http://dx.doi.org/10.1177/0148607111426276

Redhwan, A. A., Low, W. Y., Mustafa, F. M., Robert, C. and Ali, A. (2011). Perceptions about food allergy among medical science students in a university in Shah Alam, Selangor, Malaysia. International Food Research Journal, 18, 451-458.

Rosenstock, I. M., Strecher, V. J., \& Becker, M. H. (1988). Social learning theory and the health belief model. Health Education \& Behavior, 15(2), 175-183. http://dx.doi.org/10.1177/109019818801500203

Rimal, R. N. (2000). Closing the knowledge-behavior gap in health promotion: The mediating role of self-efficacy. Health communication, 12(3), 219-237. http://dx.doi.org/10.1207/S15327027HC1203_01

Russell, a. F., \& Huber, M. M. (2013). Food Allergy Management in Elementary School: Collaborating to Maximize Student Safety. Journal of Asthma \& Allergy Educators. http://dx.doi.org/10.1177/2150129713486671 
Serradell-Lopez, E., Lara, P., Castillo, D., \& González, I. (2010). Developing Professional Knowledge and Confidence in Higher Education. International Journal of Knowledge Society Research, 1(4), 32-41. http://dx.doi.org/10.4018/jksr.2010100103

Sharma, M., \& Romas, J. A. (2011). Theoretical foundations of health education and health promotion. Jones \& Bartlett Publishers.

Shek, L. P.-C., \& Lee, B. W. (2006). Food allergy in Asia. Current Opinion in Allergy and Clinical Immunology, 6(3), 197-201. http://dx.doi.org/10.1097/01.all.0000225160.52650.17

Sicherer, S. H. (2011). Epidemiology of food allergy. The Journal of Allergy and Clinical Immunology, 127(3), 594-602. http://dx.doi.org/10.1016/j.jaci.2010.11.044

Sicherer, S. H., \& Sampson, H. a. (2013). Food allergy: Epidemiology, pathogenesis, diagnosis, and treatment. The Journal of Allergy and Clinical Immunology, 133(2), 291-307.e5. http://dx.doi.org/10.1016/j.jaci.2013.11.020

Stjerna, M.-L., Vetander, M., Wickman, M., \& Olin Lauritzen, S. (2014). The management of situated risk: a parental perspective on child food allergy. Health (London, England: 1997), 18(2), 130-45. http://dx.doi.org/10.1177/1363459313481234

Wahl, A., Stephens, H., Ruffo, M., \& Jones, A. L. (2014). The Evaluation of a Food Allergy and Epinephrine Autoinjector Training Program for Personnel Who Care for Children in Schools and Community Settings. The Journal of School Nursing. http://dx.doi.org/10.1177/1059840514526889

Worm, M., Timmermans, F., Moneret-Vautrin, a, Muraro, a, Malmheden Yman, I. I., Lövik, M., ... Crevel, R. (2010). Towards a European registry of severe allergic reactions: current status of national registries and future needs. Allergy, 65(6), 671-80. http://dx.doi.org/10.1111/j.1398-9995.2010.02332.x

Wu, T.-C., Tsai, T.-C., Huang, C.-F., Chang, F.-Y., Lin, C.-C., Huang, I.-F., ... Tang, R.-B. (2012). Prevalence of food allergy in Taiwan: a questionnaire-based survey. Internal Medicine Journal, 42(12), 1310-5. http://dx.doi.org/10.1111/j.1445-5994.2012.02820.x

Wu, T.-C., Tsai, T.-C., Huang, C.-F., Chang, F.-Y., Lin, C.-C., Huang, I.-F., ... Tang, R.-B. (2012). Prevalence of food allergy in Taiwan: a questionnaire-based survey. Internal Medicine Journal, 42(12), 1310-5. http://dx.doi.org/10.1111/j.1445-5994.2012.02820.x

\section{Copyright Disclaimer}

Copyright for this article is retained by the author(s), with first publication rights granted to the journal.

This is an open-access article distributed under the terms and conditions of the Creative Commons Attribution license (http://creativecommons.org/licenses/by/3.0/). 